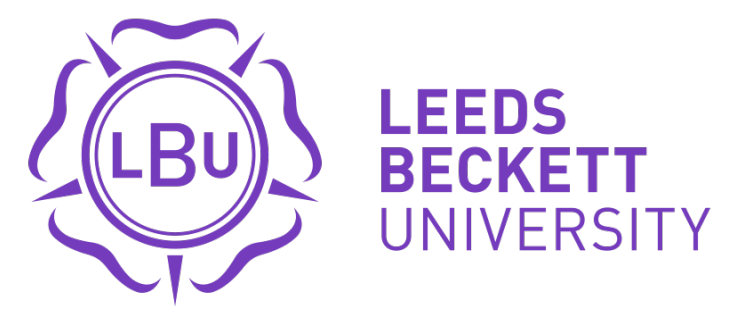

Citation:

Flintoff, A and Webb, L (2012) 'Just open your eyes a bit more': The methodological challenges of researching black and minority ethnic students' experiences of physical education teacher education. Sport, Education and Society, 17 (5). 571 - 589. ISSN 1357-3322 DOI: https://doi.org/10.1080/13573322.2011.553951

Link to Leeds Beckett Repository record:

https://eprints.leedsbeckett.ac.uk/id/eprint/270/

Document Version:

Article (Accepted Version)

The aim of the Leeds Beckett Repository is to provide open access to our research, as required by funder policies and permitted by publishers and copyright law.

The Leeds Beckett repository holds a wide range of publications, each of which has been checked for copyright and the relevant embargo period has been applied by the Research Services team.

We operate on a standard take-down policy. If you are the author or publisher of an output and you would like it removed from the repository, please contact us and we will investigate on a case-by-case basis.

Each thesis in the repository has been cleared where necessary by the author for third party copyright. If you would like a thesis to be removed from the repository or believe there is an issue with copyright, please contact us on openaccess@leedsbeckett.ac.uk and we will investigate on a case-by-case basis. 
'Just open your eyes a bit more': the methodological challenges of researching black and minority ethnic students' experiences of physical education teacher education

Anne Flintoff ${ }^{1}$ and Louisa Webb ${ }^{2}$

${ }^{1}$ Carnegie Research Institute, Leeds Metropolitan University; ${ }^{2}$ School of Sport, Exercise and Health Sciences, Loughborough University

Word count (including references): 9133

Top copy - Sport, Education and Society, Jan 2011

\footnotetext{
${ }^{1}$ Corresponding author: Carnegie Research Institute, Leeds Metropolitan University
} Leeds LS6 3QS, England 


\section{'Just open your eyes a bit more': the methodological challenges of researching black and minority ethnic students' experiences of physical education teacher education}

Abstract

In this paper we discuss some of the challenges of centralising 'race' and ethnicity in Physical Education (PE) research, through reflecting on the design and implementation of a study exploring black and minority ethnic (BME) students' experiences of their teacher education. Our aim in the paper is to contribute to ongoing theoretical and methodological debates about intersectionality, and specifically about difference and power in the research process. As McCorkel and Myers (2003) notes, the 'researchers' backstage' - the assumptions, motivations, narratives and relations - that underpin any research are not always made visible, and yet are highly significant in judging the quality and substance of the resulting project. As feminists, we argue that the invisibility of 'race' and ethnicity within PETE, and PE research more widely, is untenable; however, we also show how centralising 'race' and ethnicity raised significant methodological and epistemological questions, particularly given our position as white researchers and lecturers. In this paper, we reflect on a number of aspects of our research 'journey' : the theoretical and methodological challenges of operationalising concepts of 'race' and ethnicity; the practical issues and dilemmas involved in recruiting participants for the study; the difficulties of 'talking race' personally and professionally, and challenges of representing the experiences of 'others'. 
Key words: physical education; methodology; whiteness; power; 'race’; ethnicity; difference 


\section{Introduction}

The quote included in the title of this article is taken from an interview with a student teacher as part of a research study exploring black and minority ethnic (BME) students’ experiences of Physical Education teacher education (PETE) (Flintoff, 2008) ${ }^{\mathrm{i}}$. Her plea for us to 'open our eyes a bit more' comes from a section of the interview where she is talking about her frustration at white students and lecturers in not 'seeing' the significance of 'race' and ethnicity for Physical Education (PE), schooling, and specifically PETE. This comment serves to highlight the lack of sustained research and theorising about 'race', ethnicity and cultural diversity in PE (Macdonald, et al, 2009; Harrison and Belcher, 2006). We discuss the important work of Benn and other scholars responding to this lacuna, and acknowledge the work on 'race' in the related field of sociology of sport, below. As feminists, we suggest that this is an untenable position if such research is fundamentally about challenging oppression and inequalities in all its forms. In this paper we discuss some of the challenges of 'opening our eyes', and centralising 'race' and ethnicity in PE research, through a critical reflection on the design, implementation and reporting of the above study. Our aim is to offer a critical account of some of the challenges of reconciling complex theoretical debates around difference with the practicalities of doing empirical research (Maynard, 2002) with a particular focus on 'race' and ethnicity. We therefore address what McCorkel and Myers (2003) has called 'the researcher's backstage' - the assumptions, motivations, narratives and relations that underpin any research- but that are not always made visible in research accounts. 
A review of the national ethnic monitoring figures from English teacher education institutions provides a strong rationale for a study of BME students' experiences of PETE (Training and Development Agency, (once the Teacher Development Agency; TDA, 2008). Compared to other secondary school ${ }^{\mathrm{ii}}$ subject areas, PE remains at the bottom of the list in terms of its success in diversifying its new intakes. Over the five years from 2002-2007, just 2.09\% of PETE trainees have been from a BME background, compared to $11 \%$ choosing to opt into teaching across all subject areas (TDA, 2008; Turner, 2007). PETE in England is an overwhelmingly white space, in contrast to the increasingly ethnically diverse school populations it serves. Our research aimed to explore BME students' lived experiences of PETE. What is the significance of ethnicity in BME students' developing teacher identities, and how are these negotiated and produced within PETE in relation to other social categories, such as gender? What can an understanding of BME students' experiences tell us about the ways in which PETE practice is racialised and gendered?

In reflecting on a number of methodological and epistemological concerns in our practice, we are informed by the ideas, thinking and analytical tools from a range of theoretical positions, particularly black and post structural feminism. The paper is organised in three sections. The first overviews feminist work on difference in PE, arguing that 'race' has been both absent in terms the focus of research and in debates around the impact of power in the research process. The second provides the context and methodological approach of the study, before we move onto, in the third section, to illustrate some of the methodological and practical challenges raised by the research. The paper concludes with a call for a more sustained focus on 'race' and ethnicity as an important aspect of PE research about difference. 


\section{'Race', difference and inequality in PE and PETE}

\section{'Race' as the missing lens of difference}

Flintoff, Fitzgerald and Scraton (2008) have recently mapped the ways in which difference has been explored and researched in PE. Difference and inequality, they argue, has never been a major concern of practitioners and scholars in PE, reflecting the dominance of bio-behavioural theories of the body over the social sciences within school, university, and teacher preparation courses (Dewar, 1987; Dowling, 2006; 2008; Flintoff,1993a; 1993b). In addition, because PE has been seen to be marginal to the broader concerns of schooling, it has often been omitted from wider, critical debates of schooling and education. In assessing the developing contribution of this work, Flintoff et al (2008) argue that research in PE has an important contribution to make to wider debates in education around difference, embodiment, identity and power. For example, men and women teachers' bodies have been seen as gendered 'tools of their trade' (Webb and Macdonald, 2007a). However it is only in the related area of sport that racial stereotyping based on embodied difference has been highlighted (e.g. Hylton, 2008; Long, et al, 1997; Long, et al, 2009; Ratna, 2008). As Scraton (2001) argues, all too often, accounts of gender have assumed all women to be white, and 'race', if it has been a focus at all in research in PE and sport, has largely been taken to be a black male issue. 
Flintoff, et al (2008) also highlight that existing research has largely ignored particular differences (such as ‘race’) (but see Azzarito, 2009; Benn, 2000; Benn and Dagkas, 2006; Knez, 2007; Oliver and Lalik, 2004a; 2004b; Macdondald, et al, 2008; Wright, et al, 2003), and tends to underplay the interrelations between forms of social difference such as class, gender and disability. In this way, PE could be characterised as being 'one step behind' the wider critical debates in education that have addressed the complexity of differences and individuals' multiple identities (e.g. Archer, Hutchings, \& Leathwood, 2001; Mac An Ghail, 1994), or centred black educational experiences (e.g. Mirza, 2009; Mac An Ghail, 1988; Swain, 2003) ${ }^{\mathrm{iii}}$.

A number of scholars have responded to these limitations; the work of Benn and Dagkas (Benn, 2002; Dagkas and Benn, 2006), Macdonald, et al (2009) and Knez (2007), for example, has made important contributions. These authors adopt a theoretical lens that places 'race', ethnicity and religion at the centre of their studies and identify western and masculine definitions of sport, and racism and Islamophobia, as major issues. In addition, a small number of studies have also sought to explore the intersections of 'race' and ethnicity in boys' experiences of PE (e.g. Bramham, 2007; Fleming, 2001), highlighting the complex nature of different masculinities and their reproduction and negotiation within PE settings.

These studies aside, the marginalisation of issues of 'race' and ethnicity is particularly apparent in PE (Harrison and Belcher, 2006), and specifically in relation to research on PETE (including our own work). Whilst a developing body of work has highlighted the significance of gender and sexuality for PETE (e.g. Macdonald, 1993; Dewar, 1987; Flintoff, 1993a; b; 1994; Brown and Rich, 2002; Dowling, 2006; 2008; Rich, 2001; Sparkes et al, 2007) these studies have tended to adopt what Penney 
(2002) has called a 'single issue' approach - where gender has been fore-grounded as the focus, but with little recognition or analysis of the intersection of gender with other relations of power, particularly 'race'. As Penney (2002) concludes, these limitations reflect the intellectual and personal biographies of white researchers in PE, who have the power to determine which differences are viewed as noteworthy and get researched, and which get ignored. And, although useful, larger studies of BME students’ experiences of teacher education more broadly (e.g. Basit, et al, 2007; Carrington et al, 2001; Siraj Blatchford, 1991) have not been able to illuminate the subject specific experiences of teacher education, in this case, PE. Our research therefore addresses a number of gaps in our understandings around the racialised and gendered nature of experiences in PETE, as well as contributing to ongoing debates around embodiment and identity. Centralising 'race' and ethnicity raises important and complex questions about power and its operation in the research process, and particularly in relation to the researcher/researched relationships, to which we now turn.

\section{'Race', difference and research relationships}

A central aspect of what are now extensive epistemological debates in feminist and critical research revolve around questions over who can be a 'knower', and the significance of experience, particularly in relation to the differences or similarities between researcher and the researched (e.g. Hill Collins, 1991; Ramazanoglu and Holland, 2002). Early debates suggesting feminist research should be 'on, by and for women’ (Roberts, 1981), were quickly superseded by an acknowledgment of the dynamic, multifaceted and unpredictable nature of power relations and their effects on the research process, particularly in the use of qualitative methods such as interviews 
or ethnography (e.g. Stacey, 1998; Blair, 2004; Delamont, Oliver \& Connelly, 2001). As Archer (2002, p.109) argues, 'all researchers are partial and this partiality impacts on the research process...research is [therefore] a socially constructed process, whereby the identity of the researcher, and the methodology adopted, shape the knowledge produced'. However, there has been little sustained attention to these issues in PE research (but see, for example, Benn, 2009; Dowling and Flintoff, forthcoming; Macdonald, et al, 2007; Scraton and Flintoff, 1992; Sparkes, 1992), although more evident in the related field of sport studies (e.g. see debates in the journal Qualitative Research in Sport and Exercise; Sparkes, 2002).

The effects of 'race' and ethnicity on the research process are particularly pertinent to our research. Despite critiques from black feminists, even within wider feminist debates there has been less attention to this issue, particularly when the researchers are white, working with research participants from minority ethnic backgrounds (but see for e.g. Archer, 2002; Edwards, 1990; Hall, 2004; Howarth, 2002; Watson and Scraton, 2001). In contrast, a developing body of work by black and South Asian women have reflected on their experiences of conducting research in such circumstances, as well as with white participants (e.g. Bhopal, 2008; 2009; Mirza, 1992; Egharevba, 2001; Maylor, 2009; Phoenix, 1994). The taken-for-granted assumption that power differentials in interracial interviews, for example, can be solved by simply 'matching' the ethnicity of the researcher to that of the participant is now questioned (Bhopal, 2001; Carter, 2004; Phoenix, 1994; Sin, 2007). Gunaratnam (2007) argues that such a position contributes to essentialised views of 'race' and ethnicity by privileging one relation of difference over others such as gender, class or age. However, whilst acknowledging the complexity of 'insider/outsider' debates, 
Bhopal (2008, 2009) and Egharevba (2001) argue that being from a minority ethnic group (for Bhopal sharing the same ethnic background as her participants) and/or sharing experiences, particularly of racism, was important to the kinds of data they were able to collect. Similarly, in a study that involved researchers from different ethnic backgrounds, Archer (2002) suggests that a careful comparative analysis of interview data shows how particular issues, such as racism and whiteness, were silenced when the researcher was white. She shows how issues of gender, 'race' and feminism are all actively negotiated by interviewees and researchers in their research relationships, albeit in complex ways. She calls for more such work, particularly by white feminists, to address the ways in which their 'race' may be working to silence particular discourses and accounts.

Our reflections on power in this project have pushed us to revisit our earlier scholarship. Whilst we have previously considered our somewhat marginalised positioning as feminists and women within PE (e.g. Flintoff, 1997) it is only through this research that we have begun to reflect on our privileged position as white women (Carby, 1982; Frankenberg, 2004). We have left whiteness unmarked, leaving us in danger of reinforcing rather than deconstructing difference by exploring the dynamics of white researcher-black respondent only with BME students or teachers in this study (e.g. Flintoff, 1997; Webb, 2007a; 2007b). Before turning to reflect on these concerns more fully, we briefly describe the research context, participants and data collection methods.

\section{The research}

\section{Research context}


Our research is situated within a UK higher education policy context of 'widening access’ (Department for Education and Skills (DES), 2003; Cabinet Office, 2009; Owen, et al, 2000; Schroeder, et al, 2008) and where the monitoring and collection of data about entry and progression of students from different backgrounds has been seen as a central aspect of institutions' equality strategies. The TDA, for example, require institutions to monitor, report and use actual ethnic recruitment figures as a first step to changing and improving practice ${ }^{\text {iv }}$. They also provide small amounts of additional funding (such as that which supported this study), along with associated 'target' figures, to support institutional attempts to further BME recruitment

The impetus for our research emerged from a professional development seminar focused on ethnic diversity in PETE (Turner, 2007). Quantitative research, drawing on analyses of national ethnic monitoring data, was presented and afterwards we engaged in discussing our processes and practices, and how they might - directly or indirectly - operate to exclude or discriminate against BME students. The discussions were difficult, and it was soon evident that they had shifted from a critical reflection of PETE practices towards a 'blaming' of 'their' (BME students') culture, religion or background as reasons why 'they' didn’t apply to, or succeed in, PETE. We were uncomfortable in discussing both 'race' and ethnic difference, and our own powerful positions as white teacher educators. During the day, a strong rationale emerged to support research to explore BME students’ experiences of PETE. However, as discussed below, limiting our focus to a particular group of students identified as 'BME' through the TDA's monitoring figures, meant that our research, from the 
outset, was positioned in what Gunaratnam (2007, p.28-30) calls a 'treacherous bind'. As she explains, research that relies on racial and ethnic categories as its starting point

[can] itself can be involved in reproducing dominant conceptions of 'race' and ethnicity'.... 'Race' and ethnicity get constructed as discrete, homogenous and fixed categories of difference, rather than as socially constructed, relational and socially located.... In addition, such categorical thinking ignores the ways in which 'race' and ethnicity are 'co-constituted and reconstituted through their interrelationships with other social categories.

This situation, she suggests, may be further exacerbated when policy funders request 'neat, tidy and 'practical' solutions aimed at helping particular groups. This latter point was particularly apposite for us as the TDA requested that our report highlight the implications of our research for future recruitment and retention of BME students. In the discussion that follows, we reflect on how we sought to resolve some of the issues raised by this 'treacherous' bind. Before doing so, however, we briefly sketch the study's sample and data collection methods.

\section{Participants and data collection methods}

The study recruited twenty five BME students or recent graduates from across five English universities offering PETE courses (from a total of approximately twenty universities, nationally, offering a university-based PETE course). The research 'team' was drawn from these five universities, with researchers also holding a lecturing role within PETE in their institution. Given that the national figures of BME students in PETE in 2007/8, the year of the study, was just 65, we were pleased with 
the response to the research. We discuss some of the issues raised by these numbers below. The overview characteristics of our sample are presented in Table 1 below $^{\mathrm{v}}$. The study was multi-method, using anonymous questionnaires, followed by individual, in-depth interviews conducted by a member of the research team at the participant's own university. Interviews lasted between one to two hours, and were taped with the participants' consent. Although originally conceived of as an interview-based study, we decided that a questionnaire could provide students with a mechanism for reporting experiences that might be too difficult to discuss in a one-toone interaction. All but one of our twenty five participants involved in the interview returned a questionnaire. .

Insert Table one about here

We now turn to reflect on the key methodological challenges of the research, specifically those relating to the operationalising of concepts of 'race' and ethnicity; the practical issues and dilemmas involved in recruiting participants for the study; the difficulties of 'talking race' in interviews, and challenges of writing the experiences of 'others'.

\section{The methodological and practical challenges of researching BME students' experiences of PETE}

\section{Conceptualising and operationalising ethnicity}


The initiation of our research from within the 'treacherous bind' of ethnic categories raised complex issues from the outset. Who gets included as 'BME'? How to avoid reproducing 'race' and ethnicity as discrete, homogenous and fixed categories of difference? Like others (e.g. Walseth, 2006; Scraton, Caudwell and Holland, 2005), we conceptualise ethnic identities as heterogeneous, fluid, and actively produced across and within different social contexts, and yet acknowledge, too, the ways in which 'race' and ethnicity continue to be implicated in patterns of very real inequalities. Drawing on Brah (1996), we seek to foreground the interconnectedness of the macro and the micro starting from interviews with BME participants about their lived experiences. For Brah (1996, p.152),

...analysis of [individual] narratives must be framed against wider economic, political and cultural processes in non-reductive ways. In the framework I propose structure, culture and agency are conceptualized as inextricably linked, mutually inscribing formations.

This ‘middle way’ theorising (Archer, et al, 2001), between modernism and postmodernism, conceives identities as ‘situated accomplishments' (Valentine, 2007) in relation to material and discursive structures of inequalities.

How, then, did we reconcile the use of ethnic categories within such understandings of the nature of identity? In practice, we addressed these dilemmas by problematising ethnic categories in both our recruitment strategy, and, following Carrington, et al (2001), as part of the data collection process itself. For example, the initial email letter explicitly acknowledged the complex issues involved in the 'categorisation' of ethnicity for monitoring, good practice and research purposes. It explained that whilst the study would draw on the ethnic categories used on the national PETE application 
forms, it would be also be interested in participants' views of these as part of the study. The categories were provided at the end of the letter as a reminder. In this way, individual participants had some say in how 'BME' was operationalised in relation to their own participation within the research. The significance of phrasing our invitation in this way was highlighted by the inclusion of one student who defined herself as being of 'White British of Eastern European background' (and 'Other White Background' under the 'official' ethnic categories on her application form). TDA monitoring statistics on ethnicity excludes any 'white' students in their 'BME' figures; as Bonnett and Carrington (2000) suggest, such categorisations are 'rigid, anarchic and one-dimensional', and only describe 'visible' ethnic minorities (see also Aspinall, 2002). 'White' as a category is treated as a unitary and unproblematic category. The inclusion of this particular participant in the study clearly highlights the limitations of the term collective term 'BME' for addressing the complexities and shifting nature of racial identities and contemporary racisms.

Like those in Carrington's et al (2001) study, our participants' interviews provided rich data illustrating the inadequacy and limitations of ethnic categorisations as a basis of understanding their identities. All but two were unhappy with the official categorisation of ethnicity, particularly those of 'mixed' heritage backgrounds, the largest group of participants in our study. Students chose other ways of self definition, throwing up questions of dual or 'hyphenated' British identities. Many of the black and Asian students wanted to simply to describe themselves as British, using terms such as ‘Black British’, British Indian’, or ‘British Asian’. Interestingly, none described themselves as ‘English’, rather than British ${ }^{\mathrm{vi}}$. All students defined themselves in terms other than those used in the 'official' categories, and none felt 
that the categories reflected the realities of their multiple identities. For example, some of the Muslim students stressed the centrality of religion in their lives, important aspects of their identities that were not encompassed by a static, ethnic 'category'. Three women talked about the significance of their position as Muslim women in PE, and their struggle to challenge the often stereotypical reactions from others to their chosen career.

The positioning and experiences of the students from 'Mixed' heritage backgrounds also revealed complex processes of racialisation and the difficulties of making sense of these, empirically, if reliant on static, ethnic categories rather than lived experiences. For example, some talked about the frustrations of being seen as 'white' by their white peers, who failed to acknowledge their ethnic difference because of their reading of their skin colour and/or appearance. On the other hand, they also acknowledged this different 'reading' by others contributed to their experiences of racism being low. Such data point to the need for critical research on 'race' and ethnicity to move beyond simple black/white boundaries, to include acknowledgement of 'new ethnicities' and racisms, including 'non-colour' coded forms such as Islamophobia (Cole, 2009).

\section{Recruiting participants}

Whilst decisions about how best to invite participation in a study can appear to be simple pragmatic ones (cost and the efficacy of particular methods to recruit sufficient numbers, for example), they are also an important way in which power relations are embedded in the research process from its outset (Maynard, 2002). We were 
particularly conscious of our privileged and powerful dual roles as white lecturers and researchers, and the need to ensure students did not feel coerced into participating in the study. For this reason, we opted for the first invitation to be via email, rather than approaching students personally. We had anticipated (perhaps somewhat naively) that our universities' monitoring data on ethnicity could be used to identify possible participants. However, in gaining ethical approval for the study, we were advised by the lead University's Ethics Committee that in order to comply with the Data Protection Act (Her Majesty's Stationery Office Office, HMSO, 1998), data collected for university monitoring purposes could not be used for other purposes, such as our research. Instead, we were advised to recruit participants by contacting all students with information about the research, and ask those who considered themselves to be from a BME background to opt in. Feedback from the Ethics Committee also suggested that the Course Leaders of the PETE programmes should send the initial emails, rather than us directly ${ }^{\text {vii }}$. In addition to going some way to address the issue of coercion, this also helped situate the research as part of the everyday strategies for improving institutional practice, and reinforcing the importance of 'race' and ethnicity as important professional issues for both students and lecturers. Students interested in participating in the study emailed the locally based researcher, who then sent out full information about the research.

Although TDA funding limited the size of the project, we selected five PETE providers in order to recruit sufficient participants. These were each major ${ }^{\text {viii }}$ PETE providers; successful in recruiting BME students, and had lecturing staff interested in being involved in the research. However, in order to increase the numbers of possible participants, in addition to sending information to all current students, the information 
was also sent to up to three past cohorts for each institution (depending on the presence of BME students - some earlier cohorts had no recorded BME members!). Although we fell some way short of our initial aim of recruiting between 40-50 participants to the study (8-10 participants from each institution) we considered the response rate to be good. There may have been several reasons for this including, for example, the impact of the official backing of the project by the TDA, or the 'placing' of the lead researcher as someone established in the literature around equity in their field, albeit in relation to gender. We also felt that the professional relationships already developed with our students through our position as lecturers on their course, may have contributed positively to the participants being willing to take part. On the other hand, holding this other role may have been the key to why some students chose not to take part. As lecturers, we have a responsibility not just to ensure that students develop into confident teachers, able to employ anti-racist pedagogies, but also that we model such good practice ourselves, in our own pedagogy with PETE students (Burden, et al, 2004). In this sense, in researching the experiences of our BME students we were - at least in part - researching our own practice. It is also the case that, as our sample was self selected, we may not have recruited or being able to give 'voice' to precisely those students with the most negative PETE experiences.

The small numbers of students in our study did raise practical and theoretical issues, linked again, to the treacherous bind of ethnic categories. To ensure their anonymity, we have to report the characteristics of our sample group using the broader, Census ‘Output' categories of 'Black', ‘Asian', 'Mixed’ (as in Table 1 above). The TDA's national figures, for example, show the very small numbers of students from particular ethnicities in PETE, such as Black African or Chinese students. For the 
same reasons, we have chosen not to report students' individual viewpoints about their self or 'official' definitions of ethnicity when quoting from their interviews. These decisions are compromises, and are very much at odds with our theorising of identities as multiple, fluid and shifting (Archer, et al, 2001); yet preserving participants’ anonymity took precedence.

\section{Talking 'race' - the professional and the personal}

We noted above our difficulties as teacher educators in talking about 'race' in the seminar from which the research was initiated. This was also an issue in our research interviews. As interviewers, we sometimes struggled with words and phrases in attempting to ask questions about 'race' and racism, or respond sensitively when students told us about difficult or distressing experiences. For example, some participants reacted very defensively to our question about the impact of ethnicity on their PETE experiences. On reflection we should not have been surprised by this, given that our position in the research gave us the power to construct how others read about 'their' experiences. In another interview, one woman began to cry as she explained how alienated and frustrated she felt when white peers failed to engage in an informed way in discussions on 'race' and racism. She recounted feeling very uncomfortable in such sessions; as the only student from a BME background in her class, she was both 'invisible' and yet also 'super visible', often expected to 'talk for' all minority ethnic groups. She admitted to deliberately missing such sessions if she had the chance. We were again prompted to reflect on the adequacy of our pedagogical work on 'race' and its inseparableness from our role as researchers. 
However, being from a BME background was not in itself a guarantee of a politicized understanding of racial or other forms of inequalities as part of teachers' professional role for all students. Many talked about 'treating all pupils the same', struggling to see the relevance of university sessions on 'race' and ethnicity, particularly, as one student suggested, racism was 'no longer an issue'. Some talked stereotypically about pupils from different ethnic or gender groups, using words such as 'ethnics' or more usually 'them' to describe BME pupils. In contrast, others argued strongly that the 'facts of racism' should form a much more central part in the course in order that new PE teachers be enabled in their professional responsibilities to tackle racism in schools. There was no clear pattern as to which students appeared more politicised. As Gaine (2001) notes in relation to his research with white students, individual biographies may be important to how receptive individual students are to acknowledging racism as part of their professional responsibilities. We can only speculate on the extent to which this might be true with our participants. Our data does suggest that, for at least some of our participants, their teacher education have been largely unsuccessful in helping them see the links between the personal and professional in relation to 'race' and ethnicity.

Talking about their personal experiences of 'race' and racism also varied between participants. Some were happy to talk openly about their experiences; others were more reticent. The majority of students also did not talk directly about experiences of racism as part of their PETE courses. However, as Carrington, et al, (2001) warns, we need to read these findings cautiously; students may not wish to complain for fear of been seen as 'not coping' on their course. A small minority of students did talk openly about racism, its impact on their lives and PETE experiences, and how they 
dealt with this. Although only one student told us about a racist incident in school that was serious enough to be reported (verbal abuse from a pupil), two Asian women students had experienced incidents of abuse that had happened outside of the university context. These data highlight the significance of different experiences of racism - from specific incidents, to more of a 'feeling' of a ‘chilly atmosphere' from mentors, for example. They also show the difficulties of engaging in sensitive issues, such as racism, through interviews. As a team we had talked about the possibilities of difficult emotions being raised during the research, and, on the advice of the Ethics Committee, had prepared information to give out to support anyone who might need support, or advice about how to make a formal complaint. In practice, handing out this information seemed inadequate, and none of us actually did so.

It is not clear whether the difficulties in talking about 'race' would have been eliminated if we had shared the same ethnic or racial identity as our participants. Unlike Archer (2002), we did not have interviews conducted by researchers from BME backgrounds with which to compare ours. However, the development of rapport seemed important, and in some cases, this seemed to reflect identity aspects other than ethnicity. For example, Anne felt that her age and gender was important in developing a good rapport and openness in an interview with one of the mature women participants. Being referred to as 'Mum' by the other students initially affected her feelings of self worth and belonging, and she reported feeling 'strange' being taught by a male lecturer considerably younger than her. There were issues she may have felt more at ease discussing with an older, woman researcher. The impact of our ethnic and racial difference, on the interviews therefore was complex, and negotiated throughout interviews and could not be anticipated beforehand. 
We did explore whether and how gender had impacted upon their experiences as BME students, given the research evidence that supports this (e.g. Brown and Rich, 2002). Perhaps not surprisingly, it was the women that were more likely to reflect on their experiences as gendered, than the men ${ }^{\mathrm{ix}}$ For example, one explained that she felt her appearance and gender had played an important part in her having few experiences of racial harassment; in her words on the questionnaire: '...if I was ugly, or short, or fat or even a male, I think racial harassment incidents would have been listed in this paragraph'. Another talked about feeling intimidated by a group of taller, black boys in a lunchtime basketball session, where she felt she had had to be 'strong, and really, you know ..go in there and assert myself'. Three Muslim women each explained their different ways of negotiating swimming in what one described as the university's 'non-Islamic' facilities, highlighting the significance of their religious identity in this particular PETE space (see also Hargreaves, 2007; Birmingham City Council, 2008). These contrasted with comments from some of the men who suggested that their physicality was an important part of their pedagogy, particularly in relation to maintaining discipline with some groups. These data point to the importance of adopting an intersectional lens in order to explore the processes of racialisation, and their interrelationship with gender (Davies, 2009). They also suggest further research is warranted on the relationships between power, gender, ethnicity and physicality within PETE (Sparkes, et al, 2007).

\section{Commitments and challenges in representing the lives of 'others'}


Alexander (2006) has suggested that we not only need to attend to the politics of conducting research on 'race', as we have reflected on above - but also the poetics of research - how it is narrated, written or presented, and the relationship between the two. Feminist research is underpinned by a political and ethical commitment to account for the knowledge produced, with a consideration of the audience being critical to this (Ramazanoglu and Holland, 2002). As Ramazanoglu and Holland (2002) note however, feminists are divided on what this means in the practice; interpreting data and representing others' lives are key processes in the exercise of power in research. For example, 'taking back' the findings to participants in order to check the analysis - or 'respondent validation' - is one suggestion some have argued for. However, this is not at all straightforward, particularly when there are different understandings and political interests between participants themselves, and between participants and researchers, as highlighted earlier. Certainly one of us (Anne) deemed her previous experience of this in PETE research as far from adequate (Flintoff, 1997) ${ }^{\mathrm{x}}$. We argue that there is no one 'truth' waiting to be uncovered, only knowledge that is partial and constructed. However, like Holland et al (1998), our analysis is based on the interactions between the participants' meanings, interpretations of these in light of our feminist theory, and our explanations of any differences between the understandings of our participants and ourselves. This has entailed us in an ongoing process of reflexivity which has informed our writing of this account.

In addition, we have been particularly conscious of the ways in which we wanted our research to be received, particularly given one of our aims was to contribute to PETE practice becoming more diverse and inclusive. Whilst the final report of the project was presented to the TDA, we have also presented our work to a number of different 
groups, including to our own colleagues, both locally and nationally. The reaction to our work has been mixed. One of the positive, yet largely unanticipated results of the research, has been the numbers of students in our own institutions, including some of the participants, that have opted for a final year dissertation or project in the area of 'race' and ethnicity. It seems that the research has given the area legitimation and recognition, empowering some students to choose to develop their own knowledge and understanding of 'race' via their own projects. In the PETE community to date, we have had mainly positive reactions; at one presentation, our presentation was received enthusiastically, with many positive comments. On another occasion, in discussing some of the more concerning findings, Anne was asked whether or not 'we could rely on them as the students may not have told us the truth'! These contrasting responses demonstrate the importance of taking seriously the political implications of conducting and publishing research aimed at convincing others of the significance of the issues. Whilst the first suggests that our research has, at least, 'touched' the people involved, the second illustrates the very real challenges remaining for PETE in relation to challenging racial inequalities and addressing its whiteness, and perhaps particularly, through the use of qualitative research.

\section{Concluding comments}

This article has addressed some of the epistemological and methodological challenges of exploring BME students' experiences of PETE from our dual position of white researchers and lecturers. In doing so, we have illustrated some of the difficulties of reconciling complex theoretical debates around difference with the practicalities of conducting empirical research. In agreement with Maynard (2004), we suggest that centralising 'difference' in research raises significant operational issues that have to 
be resolved, often pragmatically but that have consequences for the overall project outcomes.

We have highlighted the challenges of research on 'race' and ethnicity that starts from ethnic categories and yet aims to show both the heterogeneity of experience and how these are racialised. We argue that despite being methodologically complex to operationalise, the use of ethnic categories remain politically and strategically important in research on 'race' and ethnicity in order to retain a focus on BME students' shared experiences of racialisation. At the same time, our data illustrates the importance of taking an intersectional lens to BME students' experiences in order to illuminate how the processes of racialisation are also gendered. While these are complex issues for both theory and research practice, we suggest that they are ones that physical educators need to engage with in a much more sustained way than is currently the case.

We have also reflected upon the dynamics of power in the process of conducting research as white researchers and lecturers, with our BME PETE students. Although such research has complex political implications, we cannot afford to use the politics of identity as an excuse for not engaging with those that are differently situated from us (Walby, 2000). There is a need for more physical educators to reveal the 'back stages' of their research and engage in reflections about these important epistemological and methodological issues and their implications for practice. In conclusion, we agree with Walby (2000) that it is only through dialogue and discussion focused on transforming practice that it is possible to bridge some of these difficult theoretical, methodological and political struggles. 


\section{Acknowledgements}

We are grateful to all the students that gave up their time to take part in the research and to Beccy Watson for her thoughtful and useful comments on earlier drafts of this paper. Thanks are also due to the full research team for their help, without which the project could not have been completed. They are: Anne Chappell, Cathy Gower, Saul Keyworth, Julia Lawrence, Julie Money, Sarah Squires and Louisa Webb.

\section{Footnotes:}

\footnotetext{
${ }^{\mathrm{i}}$ The full report is published on the TDA sponsored website, Multiverse, a resource that aims to help teacher educators and students address the educational achievements of students from diverse backgrounds (see www.multiverse.ac.uk; see also Flintoff and Money, 2009).

${ }^{\text {ii }}$ In England, the majority of secondary schools cater for children aged between 11-18 years, and most students aiming to teach in secondary school specialize in one subject area in their training - e.g. Maths, English, or PE.

${ }^{\text {iii }}$ We recognise, however, the significant attention to 'race' and ethnicity has received in the related body of literature in the sociology of sport (e.g. see Long, et al, (2009) for a good overview of some of the UK literature relating to BME participation in sport and recreation).
}

${ }^{\text {iv }}$ Despite the fact that the 2000 amendment to the UK Race Relations Act (1976) has strengthened the requirement for all public authorities to promote race equality and good race relations (Commission for Racial Equality/now the Equality and Human Rights Commission, 2008), research such as Callender, (2007) and Calender, et al, (2006), suggest there is little evidence that the gathering of statistics on ethnicity actually results in changed practices.

${ }^{\mathrm{v}}$ Our decision to report our sample using these wider ethnic categories is linked to ensuring participants’ anonymity, which we discuss below. 
${ }^{\text {vi }}$ Although space prevents a full discussion here, Rattansi (2000) argues for the importance of a historical perspective in understanding the ways in which nationality, ethnicity, and identity intersect in the lives of ethnic minorities in Britain. She argues that whilst it is now 'grudgingly accepted' that ethnic minorities can be British, their lack of whiteness continues to pose 'insuperable barriers' to being English.

${ }^{\text {vii }}$ Where one of us held the position of Course Leader, the email was sent by another Course/Programme leader in PETE.

${ }^{\text {viii }}$ In England, the TDA limit the numbers of PETE trainees that each individual institution is allowed to recruit on an annual basis. We use the term 'major' here to describe those institutions that have significant numbers $\left(40^{+}\right)$of trainees each year.

ix This is perhaps not surprisingly given the lack of reflection by men on masculinity and power in PE research (Brown and Rich, 2002; Connell, 2008).

${ }^{\mathrm{x}}$ We did however, offer all students the opportunity to read and comment on a copy of their transcript, and sent them a copy of the final report. Also, as previously mentioned, one of the unintended outcomes of the research has been the increased interest by the students themselves in carrying out their own research in the area of 'race' and ethnicity; as a result, we have continued to work and talk with several of the participants during their PETE.

\section{References}

Alexander, C. (2006) Introduction: Mapping the issues. Special issue: Writing race:ethnography and difference, Ethnic and Racial Studies, 29, 397-410. Archer, L. (2002) 'It's easier that you're a girl and that you're Asian: interactions of 'race' and gender between researchers and participants, Feminist Review, 72, 108-132.

Archer, L., Hutchings, M., \& Leathwood, C. (2001) Engaging in Commonality and Difference: theoretical tensions in the analysis of working class women's 
educational discourses, International Journal of Sociology of Education, 11, 41-62.

Aspinall, P. J. (2002) Collective Terminology to Describe Minority Ethnic Population: the persistence of confusion and ambiguity in usage, Sociology, 36, 803-816.

Azzarito, L. (2009) The Panopticon of physical education: pretty, active and ideally white, Physical Education and Sport Pedagogy, 14, 19-40.

Basit, T., Mcnamara, O., Roberts, L., Carrington, B., Maguire, M., \& Woodrow, D. (2007) 'The bar is slightly higher': the perception of racism in teacher education, Cambridge Journal of Education, 37, 279-298.

— (2002) Muslim women in teacher training: issues of gender, 'race' and religion, in: D. Penney (Ed) Gender and Physical Education: contemporary issues and future directions (London, Routledge), 57-79.

— (2009) Muslim Women in Sport: A Researcher's Journey to understanding 'Embodied Faith', International Council of Sport Science and Physical Education Bulletin, 55, 48-56.

Benn, T., \& Dagkas, S. (2006) Incompatible? Compulsory mixed-sex Physical Education Initial Teacher Training and the inclusion of Muslim women: a case study on seeking solutions, European Physical Education Review, 12, 181200.

Bhopal, K. (2001) Researching South Asian women: issues of sameness and difference in the resarch process, Journal of Gender Studies, 10, 179-286.

— (2008) Shared communities and shared understandings; the experiences of Asian women in a British University, International Studies in Sociology of Education, 18, 185-197. 
— (2009) Identity, empathy and 'otherness': Asian women, education and dowries in the Uk, Race Ethnicity and Education, 12, 27-39.

Birmingham City Council (2008) Improving Participation of Muslim Girls in Physical Education and School Sport (Birmingham, Birmingham City Council).

Blair, M. (2004) The myth of neutrality in educational research, in: Ladson-Billings \& D. Gillborn (Eds) The RoutledgeFalmer Reader in Multicultural Education (London, RoutledgeFalmer), 243-251.

Bonnett, A., \& Carrington, B. (2000) Fitting into Categories or Falling Between Them? Rethinking ethnic classification?, British Journal of Sociology of Education, 21, 487-500.

Brah, A. (1996) Cartographies of Diaspora: Contesting Identities (London, Routledge).

Bramham, P. (2003) Boys, masculinity and PE, Sport, Education and Society, 8, 5771.

Brown, D., \& Rich, E. (2002) Gender positioning as pedagogical practice in physical education, in: D. Penney (Ed) Gender and Physical Education: contemporary issues and future directions (London, Falmer), 80-100.

Burden, J., Jr,, Hodge, S., O'bryant, C. P., \& Harrison, L., Jr (2004) From Colourblindness to Intercultural Sensitivity: Infusing Diversity Training in PETE programmes, Quest, 56.

Cabinet Office (2009). Panel on Fair Access to the Professions (2009). Unleashing aspiration: the final report of the panel on fair access to the professions (London: Cabinet Office). 
Callender, D. (2007) "We've met our target" - race equality, ethnic monitoring and intial teacher education: reflections on policy and practice, paper presented at the British Educational Research Association annual conference, University of London, Sept, 2007.

Callender, D., Robinson, Y., \& Robertson, A. (2006) The impact of ethnic monitoring on the achievement of black and minority students in ITE [Internet], Research commissioned for Multiverse. Available from: www.multiverse.ac.uk [Accessed Dec 5th 2007].

Carrington, B., Bonnett, A., Demaine J, Hall I, Anoop N, Short G, Skelton C, Smith F, \& Tomlin, R. (2001) Ethnicity and the Professional Socialisation of Teachers [Internet] (London, Teacher Development Agency, Available from http://www.tda.gov.uk/partners/recruiting/consultationdata.aspx [accessed 28th Feb 2008]).

Carter, J. (2004) Research note: reflections on interviewing across the ethnic divide, International Journal of Social Research Methodology, 7, 345-353.

Cole, M. (2009) A plethora of 'suitable enemies': British racism at the dawn of the twenty-first century, Ethnic and Racial Studies, 32, 1671-1685.

Commission for Racial Equality (2008) Ethnic Monitoring: A Guide for Public Authorities [Internet] (London, Commision for Racial Equality. Available from www.cehr.gov.uk [Accessed 1st Feb, 2008]).

Dagkas, S., \& Benn, T. (2006) Young Muslim women's experiences of Islam and physical education in Greece and Britain: a comparative study, Sport, Education and Society, 11, 21-38.

Davies, K. (2008) Intersectionality as buzzword. A sociology of science perspective on what makes a feminist theory successful, Feminist Theory, 9, 67-85. 
Delamont, S., Oliver, K., \& Connelly, P. (2001) Review symposium: Taking Sides in Social Research: essays on partisan and bias, Martyn Hammersley, 2000, London, Routledge, British Journal of Sociology of Education, 22, 157-169. Department for Education and Science (2003). Widening Participation in Higher Education. London: The Stationary Office.

Dewar, A. (1987) The social construction of gender in physical education, Women Studies International Journal, 10, 453-465.

Dowling, F. (2006) Physical education teacher educators' professional identities, continuing professional development and the issue of gender equality, Physical Education and Sport Pedagogy, 11, 247-263.

— (2008) Getting in touch with our feelings: the emotional geographies of gender relations in PETE, Sport, Education and Society, 13, 247-266.

Dowling, F., \& Flintoff, A. (forthcoming) Getting beyond normative interview talk of sameness and celebrating difference, Qualitative Research in Sport and Exercise.

Edwards, R. (1990) Connecting method and epistemology: a white woman interviewing black women, Women's Studies International Forum, 13, 477490.

Egharevba, I. (2001) Researching an-'other' minority ethnic community: reflections of a black female researcher on the intersections of race, gender and other power positions within the research process, International Journal of Social Research Methodology, 4, 225-241.

Fleming, I. (1991) Sport, schooling and Asian male youth culture, in: G. Jarvie (Ed) Sport, Racism and Ethnicity (London, Falmer). 
Flintoff, A. (1993a) Gender, Physical Education and Teacher Education, in: J. Evans (Ed) Equality, Education and Physical Education (London, Falmer), 184-204.

— (1993b) One of the boys? Gender identities in Physical Education initial teacher education, in: I. Siraj-Blatchford (Ed) 'Race', Gender and the education of teachers. (Buckingham, Open University Press), 74-93.

— (1997) Gender Relations in Physical Education Initial Teacher Education, in: G. Clark \& B. Humberstone (Eds) Researching Women and Sport (London, Macmillan Press), 164-182.

Flintoff, A., with Chappell, A., Gower, C., Keyworth, S., Lawrence, L., Squires, S. L., \& Webb, L. (2008) Black and Minority Ethnic trainees' Experiences of Physical Education Initial Teacher Training (Leeds, Leeds Metropolitan University/Teacher Development Agency).

Flintoff, A., Fitzgerald, H., \& Scraton, S. (2008) The Challenges of Intersectionality: Researching difference in Physical Education, International Studies in Sociology of Education, 18, 73-85.

Flintoff, A., \& Money, J. (2009) Does ethnicity matter? Black and ethnic minority students' experiences of Physical Education teacher education,, Physical Education Matters, 4, 34-39.

Gaine, C. (2001) If it's not hurting it's not working: teaching teachers about 'race', Research Papers in Education, 16, 93-113.

Gunaratnam, Y. (2003) Researching 'Race' and Ethnicity: Methods, Knowledge and Power (London, Sage).

Hall, R. A. (2004) Inside out: some notes on carrying out feminist research in crosscultural interivews with South Asian women immigration applicants, International Journal of Social Research Methodology, 7, 127-141. 
Hall, S. (2000) Conclusions: The multi-cultural question, in: B. Hesse (Ed) Un/Settled Multiculturalisms: Diasporas, Entanglements, Transruptions (London, Zed Books).

Hargreaves, J. (2007) Sport, exercise and the female Muslim body: negotiating Islam, politics and male power, in: J. Hargreaves \& P. Vertinsky (Eds) Physical Culture, Power and the Body (London, Routledge), 74-100.

Harrison, L., Jr, \& Belcher, D. (2006) Race and ethnicity in physical education, in: D. Kirk, D. Macdonald \& M. O'Sullivan (Eds) The Handbook of Research in Physical Education (London, Sage), 740-751.

Her Majesty's Government Stationary (HMSO)[Internet] (1998). Data Protection Act, 1998. Available from www.legislation.gov.uk [Accessed Oct 15th, 2010].

Hill Collins, P. (1991) Black Feminist Thought: Knowledge, Consciousness and the Politics of Empowerment (London, Routledge).

Holland, J., Ramazanoglu, C., Sharpe, S., \& Thompson, J. (1998) The Male in the Head: Young People, Heterosexuality and Power (London, Tufnell Press). Hylton, K. (2008) 'Race'and Sport: Critical Race Theory (London, Routledge). Knez, K. (2007). The meaning and place of physical activity in the lives of young Muslim women. Unpublised PhD thesis, University of Queensland, Australia.

Long, J., Carrington, B., \& Spracklen, K. (1997) 'Asians Cannot Wear Turbans in the Scrum': Explanations of racist discourse within professional rugby league, Leisure Studies, 16, 249-259.

Long, J., Hylton, K., Sparklen, K., Ratna, A., \& Bailey, S. (2009). Systematic Review of Literature on Black and Ethnic Minority Communities in sport and physical recreation. Leeds: Carnegie Research Institute, Leeds Metropolitan University, for The UK Sports Councils and Sporting Equals. 
Mac an Ghaill, M. (1988) Young, Gifted and Black. (Buckingham, Open University Press.).

Macdonald, D. (1993) Knowledge, Gender and Power in Physical Education Teacher Education, Australian Journal of Education, 37, 259-278.

Macdonald, D., Abbott, R., Knez, K., \& Nelson, K. (2009) Taking exercise: cultural diversity and physically active lifestyles, Sport, Education and Society, 14, 119.

Maylor, U. (2009) Is it because I'm Black? A Black female research experience, Race Ethnicity and Education, 12, 53-64.

Maynard, M. (2002) Studying age, 'race' and gender: translating a research proposal into a project, International Journal of Social Research Methodology, 5, 3140.

McCorkel, J. A., \& Myers, K. (2003) What Difference does Difference Make? Position and Privilege in the Field, Qualitative Sociology, 26, 199-231.

Mirza, H. S. (1992) Young, Female and Black. ( London, Routledge.).

— (2009) Race, Gender and Educational Desire: Why Black Women Succeed and Fail (London, Routledge).

Oakley, A. (1981) Interviewing women; a contradiction in terms, in: H. Roberts (Ed) Doing Feminist Research (London, Routledge).

Oliver, K., \& Lalik, R. (2004a) 'The Beauty Walk': Interrogating whiteness as the norm for beauty within one school's hidden curriculum., in: J. Evans, B. Davis \& J. Wright (Eds) Body Knowledge and Control: studies in the sociology of physical education and health (London, Routledge), 115-129. 
Oliver, K. L., \& Lalik, R. (2004b) "The Beauty Walk, this ain't my topic': learning about critical inquiry with adolescent girls", Journal of Curriculum Studies,, 36, 555-586.

Owen, D., Green, A., Pitcher, J., \& Maguire, M. (2000). Minority Ethnic Achievements and participation in Education: Training and the Labour market, DfEE Research Report 225. London: Department for Education and Employment.

Penney, D. (2002) Equality, equity and inclusion in Physical Education, in: A. Laker (Ed) The Sociology of Sport and Physical Education (London, Routledge), 110-128.

Pheonix, A. (1994) Practising feminist research: the intersection of gender and 'race' in the research process, in: M. Maynard \& J. Purvis (Eds) Researching women's lives from a feminist perspective (London, Taylor and Francis), 4971.

Ramazanoglu, C., \& Holland, J. (2002) Feminist Methodology: Challenges and Choices (London, Sage).

Ratna, A. (2008). British Asian Females' Racialised and Gendered Experiences of Identity and Women's Football, unpublished $\mathrm{PhD}$ thesis, University of Brighton, England.

Rattansi, A. (2000) On Being and Not Being Brown/Black-British, interventions, 2, 118-134.

Rich, E. (2001) Gender positioning in teacher education in England: new rhetoric, old realities', International Studies in Sociology of Education, 11, 131- 154.

Roberts, H. (1981). Doing Feminist Research (London, Routledge). 
Schroeder, A., Miles, A., Savage, M., Halford, S., \& Tampubolon, G. (2008). Mobility, careers and inequalities: a study of work-life mobility and the returns from education, Research Report 8. London: Equality and Human Rights Commission.

Scraton, S. (2001) Re-conceptualising race, gender and sport: the contribution of black feminism',, in: B. Carrington \& I. McDonald (Eds) Race, Sport and British Society (London, Routledge), 170-187.

Scraton, S., Caudwell, J., \& Holland, S. (2005) Bend it like Patel: Centering 'Race', Ethnicity and Gender in Feminist analysis of women's football in England, International Review for the Sociology of Sport, 40, 71-88.

Scraton, S., \& Flintoff, A. (1992) Feminist Research and Physical Education, in: A. C. Sparkes (Ed) Research in Physical Education and Sport (London, Falmer), 167-187.

Sin, H. C. (2007) Ethnic-matching in qualitative research; reversing the gaze on 'white' others and 'white' as other, Qualitative Research, 7, 477-499.

Siraj-Blatchford, I. (1991) A study of black students' perceptions of racism in initial teacher education, British Educational Research Journal, 17, 35-50.

Sparkes, A. (2002) Telling Tales in Sport and Physical Activity: A Qualitative Journey (Leeds, Human Kinetics).

Sparkes, A., Partington, E., \& Brown, D. (2007) Bodies as bearers of value: the transmission of jock culture via the 'Twelve Commandments', Sport, Education and Society, 12, 295-316.

Stacy, J. (1988) Can there be a feminist ethnography?, Women's Studies International Forum, 11, pp.21-27. 
Teacher Development Agency (2008) Statistics provided on request by personal communication, February 2008.

Turner, D. (2007) Ethnic Diversity in Physical Education Teaching, Physical Education Matters, 2, 14-16.

Valentine, G. (2007) Theorizing and researching Intersectionality: A challenge for feminist geography, The Professional Geographer, 59, 10-21.

Walby, S. (2000) Beyond the politics of location: the power of argument in a global era, Feminist Theory, 1, 189-206.

Walseth, K. (2006) Young Muslim Women and Sport: the impact of identity work, Leisure Studies, 25, 75-94.

Watson, B., \& Scraton, S. (2001) Confronting Whiteness? Researching the leisure lives of South Asian mothers, Journal of Gender Studies, 10, 265-278.

Webb, L. A., \& Macdonald, D. (2007a) Dualing with gender: Teachers' work, careers and leadership in physical education, Gender and Education, 19, 491-512.

Webb, L. A., \& Macdonald, D. (2007b) Techniques of power in physical education and the under-representation of women in leadership, Journal of Teaching in Physical Education, 26, 277-295. 